Session 3441

\title{
ABET 2000 and Ethics: Partnering with Librarians to Embed Ethics Into Course Curricula
}

\author{
Alice J. Trussell, Daryl Youngman \\ Kansas State University
}

\begin{abstract}
The ultimate expectations that all Colleges of Engineering are challenged to meet are the Accreditation Board for Engineering and Technology [ABET] criteria. Included in the ABET 2000 criteria are very specific requirements for Colleges of Engineering to provide substantive course content focusing on ethical education and decisions that engineers will face in the real world. Ethics requirements are listed alongside technical and other social competencies.
\end{abstract}

Science and engineering librarians are in an excellent position to partner with engineering faculty to design and participate in course content and instruction. Specific issues involving ethics are woven through the fabric of library instruction. Information literacy focuses on educating engineering students about thoughtful evaluation of web and scholarly resources. As the presence of the Internet grows exponentially, we cannot assume that students are equipped with skills to objectively research and evaluate resources. In addition, the 'Napster Generation' can have an entirely different perspective on fair use and appropriation of information accessed, resulting in problems ranging from improper citation of resources to plagiarism. This paper will focus on the convergence of these important contextual elements followed by specific ways that engineering and library faculty can partner to include ethics within the context of both programmatic and course offerings. Engineering librarians and faculty are encouraged to share further ideas of specific subject content applicable to the infusion of ethics in course instruction.

Introduction

Changes in engineering education are visible on several fronts. ABET 2000+ introduced a host of challenging expectations that encompass values as well as scales of academic achievements. Colleges of Engineering are working more closely with partner corporations. New engineering students bring with them different educational experiences, different information-seeking patterns, and different attitudes and expectations about the proper access and use of information. Each of these factors can have appreciable impact on the perspective that students have relative to ethics. Engineering educators are challenged to grapple with these factors as they strive for program excellence and accountability.

Engineering librarians have enjoyed a positive, long-standing tradition of facilitating information access and retrieval to engineers, engineering faculty, and engineering students. In the days of paper-based information, this remained a stable relationship based upon decades of tradition. The librarian organized and warehoused the information and the patron came to the library in 
order to access the information. One large goal of the library was to acquire and locally provide as much information as fiscally possible in order to be ready for the request just in case the patron required any specific item. Library instruction normally consisted of acquaintance with card catalogs, indexes, and classification schemes, with reminders to give credit for quotations and chunks of information gleaned directly from sources. Patrons functioned within a system of well-defined parameters guiding them through the information search process.

Easy electronic access to the Internet and scholarly information created a dynamic restructuring of the library / College of Engineering relationship. Instant access at the click of a keyboard empowered users to find information far beyond the scope of the traditional library printed materials reservoir. Patrons would arrive with an idea that search engines such as Google or Alta Vista were the gateways to information heaven. The distinction between scholarly and nonscholarly information became blurred for many users. Simultaneously, librarians were suddenly faced with the task of not only organizing the scholarly electronic information into navigable web pages, but educating patrons about correct usage of these library resources as well as the "free" resources from the world at large. Faculty began seeing students who not only equated scholarly research with web searches, but who viewed the ability to copy and paste as a precursor to ownership and authorship of prose.

This technological revolution has necessitated that librarians work in collaboration with engineering faculty to better educate engineering students in the realities of scholarly research. The librarian is in a position to teach practical tools enabling evaluation of resources, critical thinking skills, and appropriate citation practices. Ethical research and writing requires correct usage of information resources.

\section{ABET 2000+}

Included in the qualitative measurements introduced in the ABET 2000 criteria were requirements specifying that graduates have an understanding of ethical responsibilities and that they incorporate that knowledge in a major design experience. These requirements are found in Criteria 3 and 4. Criterion 3, Program Outcomes and Assessment, states "Engineering programs must demonstrate that their graduates have: ...(f) an understanding of professional and ethical responsibility. ... Each program must include an assessment process with documented results."

Criterion 4, Professional Component, builds upon the outcomes of Criterion 3: "Students must be prepared for engineering practice through the curriculum culminating in a major design experience based on the knowledge and skills acquired in earlier course work and incorporating engineering standards and realistic constraints that include most of the following considerations; economic; environmental; sustainability; manufacturability; ethical; health and safety; social; and political.",2

The Role of the Librarian

Professional and ethical responsibilities (see Criterion 3 above) include a broad spectrum of activities. One critical lifelong activity is knowledgeable information access, retrieval, and usage. As engineering faculty strive to include demonstrable components in curricula and course 
content to include ethical training, the librarian can provide input, collaboration, and specific instruction.

Whether or not librarians choose to embrace the fact, new roles have been created for them. Many libraries are now pursuing initiatives that are deliberately structured to emphasize direct contact between library subject specialists and academic departments. However, even proponents of increased library electronics note that traditional services are an integral part of any future reference service model. ${ }^{3}$ Response to the need for interaction between teaching faculty and librarian should not, however, be limited to a reference desk. Remote users may need as much, or more, librarian assistance as in-person users. Technology now allows the implementation of services that can be quite effective in extending service to distant users.

Increasingly, librarians are finding themselves employed as content developers- i.e., contributors to or developers of a variety of information resources served to patrons across the Web, often through digital library setup. Web tutorials, locally developed databases, and specialized subject assistance Web pages are examples.

As librarians fulfill these new roles, engineering faculty can collaborate with the librarian to incorporate a variety of these delivery modes into class work and instruction. Ethics components are a natural inclusion to the breadth and width of these curricular activities. Librarians should be paying attention not only to developing partnering arrangements and improving their librarybased instructional programming, they should also be improving the user (electronic) interface to better accommodate the delivery of ethics education. ${ }^{4}$

Information Literacy

A popular concept in the library community since the late 1980's has been the idea of information literacy. While a person may be 'literate' and have an ability to read, an 'information literate' person appropriately incorporates critical thinking skills in mentally processing the material. The Association of College and Research Libraries [ACRL] defines information literacy as "a set of abilities requiring individuals to 'recognize when information is needed and have the ability to locate, evaluate, and use effectively the needed information"5 Academic communities are recognizing the need for all students to master the skill set of information literacy competencies. ${ }^{6}$

ACRL further defines the skill set of abilities needed by an information literate person as:

- Determine the extent of the information needed

- Access the needed information effectively and efficiently

- Evaluate information and its sources critically

- Incorporate selected information into one's knowledge base

- Use information effectively to accomplish a specific purpose

- Understand the economic, legal, and social issues surrounding the use of information, and access and use the information ethically and legally ${ }^{7}$

Engineering faculty and librarians can plan to incrementally incorporate information literacy skill training into departmental curricula. The ACRL recommended skill set coordinates 
extremely well with the skill set and requirements reflected in ABET Criteria 3 and 4. Thorough information literacy training will inherently require the patron to critically evaluate the entire information access process and subsequently enable the user to more effectively consider the economic, legal, social and ethical issues of using the information.

The Student

Dr. Fred Newton, Director of University Counseling Services at Kansas State University, has been professionally observing the behaviors of students for over 30 years. Dr. Newton concludes that the 'millennial student' truly is different due to the infusion of technology beginning about 1980. Most students today have grown up with the computer as a part of their worlds of recreation and education. Dr. Newton believes this generation is the most informed generation to have ever lived on the planet. However, "although students have more general knowledge, they come to our campuses with less experience in exercising the discipline and focus required to explore a subject in depth.",

Students arriving at college are often ill prepared to grapple with the information resources presented by the modern academic library. Compounding the problem is the fact that many students have come to believe that accessing and using information is simple, a belief supported by commercial marketing practices and popular usage of the Internet. In part because the Internet is so often billed as easy to use, even patrons working in the library hesitate to ask librarians for help. Popular usage may be easy, but effective research usage is not. As Alan November, technology educator and consultant stated, "Many young people can be deluded by a false sense of confidence when they think they know what they are doing. Students and adults alike too often mistake technical mastery with critical thinking." ${ }^{9}$ Librarians often presume that students have now "grown up with computers" but, in many cases, students arrive at college with no significant training in information literacy concepts as defined by ACRL. ${ }^{10}$ Many secondary schools claim to integrate information technology into the curriculum but, in fact, this training is often neither monitored nor evaluated. Only in rare instances have educational standards been established for such skills. Students, as Weiler so aptly puts it, often simply do not "know all that stuff". ${ }^{11}$

Further studies of student behavior using technology, however, reveal that many students hold different convictions or values about what constitutes cheating or plagiarism. Dr. Donald McCabe, Professor at Rutgers University and founder of the Center for Academic Integrity, contends that "most students have concluded that 'cut \& paste' plagiarism-using a sentence or two (or more) from difference sources on the Internet and weaving this information together into a paper without appropriate citation - is not a serious issue."12 Dr. McCabe's interviews with many of the students reveal that the students genuinely believe they have done nothing wrong because they are doing 'research'. Many students do not think a citation is necessary because of the belief that everything on the Internet is public information. ${ }^{13}$ The seriousness of that simple misbelief is compounded by the fact that sometimes students will view academic resources offered through the library as "Internet" resources because they are accessed via the Web. 
Implementation

Statistics have shown that when an institution has an honor code and faculty specifically discusses with students what constitutes acceptable and unacceptable behavior, rates of plagiarism and dishonesty are measurably reduced. ${ }^{14}$ The first step requires the faculty to take the time and effort to clearly outline that policy and give specific examples of behavior that constitutes plagiarism. $^{15}$

Given the pervasive problem with plagiarism and academic dishonesty, librarians need to specifically highlight and emphasize the components of information literacy training focused on ethics. Clearly labeling these components as "ethical" choices communicates to the students that these issues are ethical issues, not just something that is a custom or a literary preference. Coupled with continuing specificity within each classroom environment, successful ethics training can occur.

In addition to simply outlining specific ethical practices and principles, a comprehensive effort to infuse ethics in information retrieval and use needs to be implemented across the curricula of the college. The engineering librarian is equipped to work with engineering faculty to train students in skills needed to be information literate. In "Information Competencies: A Strategic Approach," Nerz and Weiner detail efforts at North Carolina State University to integrate information literacy into course curriculum in the College of Textiles and Engineering. Their findings demonstrated that a random approach of periodic library orientation sessions or projects did not accomplish the full complement of information literacy skills desired. They concluded that information skills training needed to be embedded across the curricula; an incremental implementation on a grade level basis can achieve specific competencies through progressive assignments. ${ }^{16}$

Library and engineering faculty can begin to list the kinds of topics that are important for students to address. Possible topics for discussion and instruction could begin with, but not be limited to, these kinds of issues:

1. What is academic research?

2. How are academic (or library) resources distinguished from other Web resources?

3. How is thoroughness - finding 'both sides' — an ethical responsibility?

4. What acquired information needs to be cited?

5. How do you cite information?

6. Define plagiarism.

7. What do you do when the uncovered scholarly information disagrees with what you are supposed to do or prove?

8. What are the ethical issues involved with presenting non-scholarly information as scholarly?

Engineering librarians can greatly benefit by thoughtful collaboration amongst themselves to ascertain the specific incremental instruction components that can be integrated across the curriculum. Librarians can then approach engineering faculty with concrete suggestions that can be a basis for specific additions that are important to the college curricula. Engineering faculty 
members are encouraged to approach librarians with ideas and suggestions of ethics based instructional issues particularly relevant to a given course or discipline.

In order to satisfy ABET $2000+$ requirements and verify success of the training, an assessment component must be built into the training program. ${ }^{17}$ Librarians and engineering faculty both need to be prepared to make adjustments based upon results found within the cycle of assessment.

Summary and Conclusion

In summary, a convergence of facts and circumstances dictate that specific measures be taken to deliberately include ethics training and assessment in the curricula of Colleges of Engineering. Expectations for engineering education have changed. Qualitative requirements have been implemented by ABET, challenging Colleges of Engineering to include specific training in values that include ethics. Corporate partners are working more closely with colleges and have expectations of hiring 'good people' as well proficient engineers. Libraries have undergone a virtual transformation with the coming of the age of electronic access to and delivery of information. At the same time, technologically advanced students are arriving on campus with varying perspectives on what actually constitutes the concepts of honesty and plagiarism. Librarians and engineering faculty are both striving to meet the increased demands created by all of these changes.

As expectations for engineering programs have grown, an important tool for achieving those expectations will be the implementation of a program of information literacy skills training. By designing a comprehensive curricular program, the efforts of engineering faculty and librarians together can achieve far more than either can individually.

\footnotetext{
1 "Criteria for Accrediting Engineering Programs Effective for Evaluations during the 2003-2004 Accreditation Cycle." p. 1. November 2, 2002. Accessed January 13, 2004. <http://www.abet.org/images/Criteria/E1\%200304\%20EAC\%20Criteria\%2011-15-02.pdf>

${ }^{2}$ Criteria for Accrediting Engineering Programs Effective for Evaluations during the 2003-2004 Accreditation Cycle." p. 2. November 2, 2002. Accessed January 13, 2004. <http://www.abet.org/images/Criteria/E1\%200304\%20EAC\%20Criteria\%2011-15-02.pdf>

${ }^{3}$ McKenzie, Jamie. Questioning, Research and the Information Literate School. FNO Press. Bellingham, Washington. 2000. p. 127.

${ }^{4}$ Newins, Nancy. "Investigating the Interface: A New Role for Instruction Librarians." Virginia Libraries 1999. Vol. 45 n 1. p 11-12.

${ }^{5}$ Association of College and Research Libraries. "Information Literacy Competency Standards for Higher Education.” January 18, 2000. Accessed January 13, 2004. $<$ http://www.ala.org/Content/NavigationMenu/ACRL/Standards_and_Guidelines/standards.pdf>

${ }^{6}$ Nerz, Honora F., and Suzanne T. Weiner. "Information Competencies; A Strategic Approach." Proceedings of the 2001 American Society for Engineering Annual Conference \& Exposition. 2001. Session 2241.

${ }^{7}$ Association of College and Research Libraries. "Information Literacy Competency Standards for Higher Education.” January 18, 2000. Accessed January 13, 2004.

$<\mathrm{http}$ //www.ala.org/Content/NavigationMenu/ACRL/Standards_and_Guidelines/standards.pdf $>$

${ }^{8}$ Newton, Fred B. "The New Student." About Campus. November--̄December 2000. p. 9, 11. Accessed January 13, 2004. <http://www-personal.ksu.edu/ newtonf/interests/research/newstudent/newstudent.pdf>
} 


\footnotetext{
${ }^{9}$ November, Alan. Empowering Students With Technology. Skylight Training and Publishing Inc. Glenview, IL. 2001. p.16.

${ }^{10}$ Association of College and Research Libraries. "Information Literacy Competency Standards for Higher Education.” January 18, 2000. Accessed January 13, 2004.

${ }^{11}$ Weiler, Angela. "Two-Year College Freshman and the Internet: Do They Really Know 'All That Stuff'?" Portal: Libraries and the Academy. 2001. Vol. 1 n. 2. p. 161-167 July 23, 2001.

${ }^{12} \mathrm{McCabe}$, Donald L. "CAI Research" The Center for Academic Integrity, Kenan Institute for Ethics, Duke University. Accessed January 13, 2004. http://www.academicintegrity.org/cai_research.asp

${ }^{13}$ Clarke-Pearson, Mary. "Download. Steal Copy. Cheating at the University." The Daily Pennsylvanian. November 27, 2001. Accessed January 13, 2004.

$<$ http://www.dailypennsylvanian.com/vnews/display.v/ART/2001/11/27/3c03502bad345?in_archive=1>

${ }^{14}$ McCabe, Donald L. "CAI Research" The Center for Academic Integrity, Kenan Institute for Ethics, Duke University. Accessed January 13, 2004. http://www.academicintegrity.org/cai research.asp

${ }^{15}$ McCullen, Caroline. "Preventing Digital Plagiarism.” Technology \& Learning. Vol. 22 n. 9 (April 2002) p. 8.

${ }^{16}$ Nerz, Honora F., and Suzanne T. Weiner. "Information Competencies; A Strategic Approach." Proceedings of the 2001 American Society for Engineering Annual Conference \& Exposition. 2001. Session 2241. Best Paper Award, 2001 ASEE Annual Conference.

${ }^{17}$ Smith, Kenneth R. "New Roles and Responsibilities for the University Library: Advancing Student Learning Through Outcomes Assessment.” ARL 213 (2000). p. 2-5.
}

\section{ALICE J. TRUSSELL}

Alice Trussell currently serves as an Assistant Professor for Kansas State University Libraries and is the Director of the Fiedler Engineering Library. Her research interests include information literacy, science and technology library design, innovative web resource design, and the information needs of persons with neurotological disorders. She is a member of Beta Phi Mu, the International Library and Information Studies Honor Society, and Sigma Xi.

\section{DARYL C. YOUNGMAN}

Daryl Youngman currently serves as Associate Professor and Interim Assistant Dean for Library Administration at Kansas State University. His research interests include integration of library resources into the curriculum, and the changing roles of academic librarians. He conducts consulting activities related to library service quality. He serves on the editorial board of Issues in Science and Technology Librarianship and is a member of Sigma Xi. 